\title{
Acute spinal epidural hematoma: A case report and review of the literature
}

\author{
Ezgi Akar, M.D.,' 1 Ahmet Öğrenci, M.D., ${ }^{2}$ (1) Orkun Koban, M.D., ${ }^{2}$ \\ Mesut Yılmaz, M.D., ${ }^{3} \odot$ Sedat Dalbayrak, M.D. ${ }^{2}$
}

\begin{abstract}
1'Department of Neurosurgery, University of Health Sciences, Haydarpaşa Numune Training and Research Hospital, İstanbul-Turkey
${ }^{2}$ Department of Neurosurgery, Okan University Faculty of Medicine, İstanbul-Turkey

${ }^{3}$ Department of Neurosurgery, Neurospinal Academy, İstanbul-Turkey
\end{abstract}

\begin{abstract}
Spinal epidural hematoma (SEH) is a rare but a significant cause of spinal cord compression and neurologic deficits. Its etiology is usually unknown and requires emergency intervention. The present study aims to review the clinical significance, treatment strategies and clinical outcomes of traumatic SEH with a rare case presentation. Our patient was a 42-year-old female who presented with back pain and loss of sensation and strength in the legs. The patient did not have any disease and did not use anticoagulant drugs. The patient developed numbness in her legs half an hour after having a traditional back walking massage due to occasional back pain. She was paraplegic and anesthetic when seen in our clinic. Thoracic computed tomography (CT) and magnetic resonance imaging (MRI) revealed posterior epidural hemorrhage at Th3-Th4 levels. In the $12^{\text {th }}$ hour, the hematoma was evacuated by an emergency decompressive hemilaminectomy. At the postoperative $24^{\text {th }}$ hour, the patient had symptomatic improvement, and in the sixth month, the patient was mobilized with support. SEH is a rare condition that should be considered in patients with sudden onset of back pain and extremity weakness. Although the gold standard diagnostic tool is MRI, CT is often sufficient to avoid delayed surgery. Immediate surgical decompression (laminectomy/hemilaminectomy) should be performed in cases diagnosed with SEH with neurological deficits.
\end{abstract}

Keywords: Decompressive surgery; hemilaminectomy; magnetic resonance imaging; spinal epidural hematoma.

\section{INTRODUCTION}

Spinal epidural hematoma $(\mathrm{SEH})$ is a very rare but a serious cause of acute neurological deterioration requiring early diagnosis and rapid surgical treatment. SEH has two different types as traumatic and spontaneous. ${ }^{[1]}$ According to the literature data, traumatic SEH occurs in 0.5 to I.7\% of all spine traumas, but the incidence increases up to $9 \%$ in patients with rheumatologic disease. ${ }^{[2]}$ Approximately 20-30\% of all SEHs occur due to post-traumatic reasons. ${ }^{[3]}$ Traumatic SEH may appear with traumatic spine injuries, as a complication of postoperative surgical procedures (e.g., instrumentation procedures, vertebro and kyphoplasty) and after spinal injection procedures.
[3] Traumatic SEH may sometimes occur even with a simple lumbar puncture procedure $(0.1 \%-0.24 \%) .{ }^{[4]}$ According to the literature data, there are several cases with $\mathrm{SEH}$ with minor trauma that arise from spine manipulation therapy. ${ }^{[4]}$

In the present study, we discussed a case who was admitted to our emergency department with SEH with progressive neurological deficits after having back walking massage, which is an ancient Eastern massage method (Fig. I). We discussed our case who underwent surgical treatment due to thoracal $\mathrm{SEH}$ in the light of the current literature. To our knowledge, there is no reported case with SEH after back walking massage in the literature.

Cite this article as: Akar E, Öğrenci A, Koban O, Yılmaz M, Dalbayrak S. Acute spinal epidural hematoma: A case report and review of the literature. Ulus Travma Acil Cerrahi Derg 2020;26:628-631.

Address for correspondence: Ezgi Akar, M.D.

Haydarpaşa Numune Eğitim ve Araştırma Hastanesi, Beyin ve Sinir Cerrahisi Kliniği, İstanbul, Turkey

Tel: +90 216 - 3868263 E-mail: ezgiaycicek@gmail.com

Ulus Travma Acil Cerrahi Derg 2020;26(4):628-63I DOI: 10.14744/tjtes.2019.60956 Submitted: 30.09.2019 Accepted: 15.12.2019 Online: I5.06.2020

Copyright 2020 Turkish Association of Trauma and Emergency Surgery 


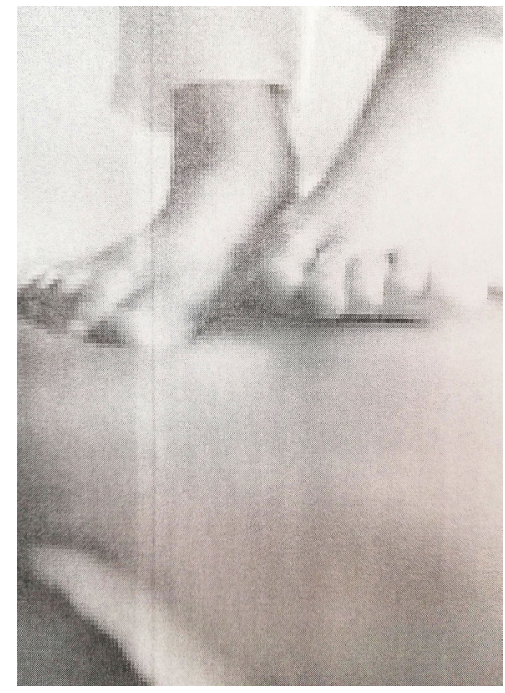

Figure 1. Back walking massage.

\section{CASE REPORT}

A 42-year-old female patient was admitted to the emergency department due to back pain, and acute onset of sensory changes and weakness in the lower extremity.

The patient was referred to us from another center. When the patient was evaluated in the emergency department, about 10 hours had passed since the beginning of the incident. The patient was conscious and without respiratory distress and with normal vital signs. Physical examination revealed anesthesia below Th3 level and paraplegia, and lack of anal sensation and tonus. She had no history of hypertension, severe trauma, anticoagulant drug use and bleeding dyscrasia. The patient stated that someone had walked on her back to
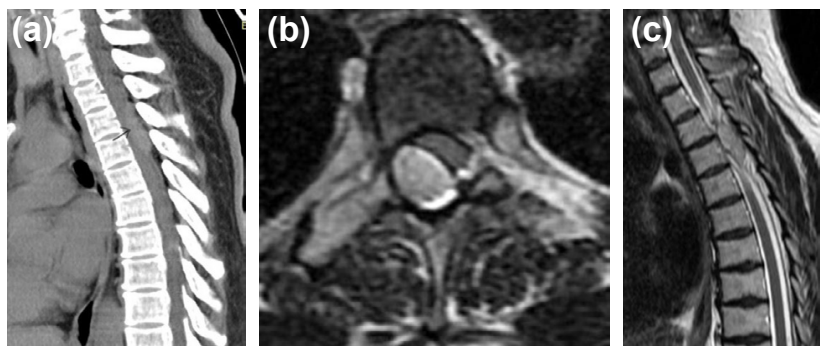

Figure 2. (a-c) Preoperative CT and MRI images.
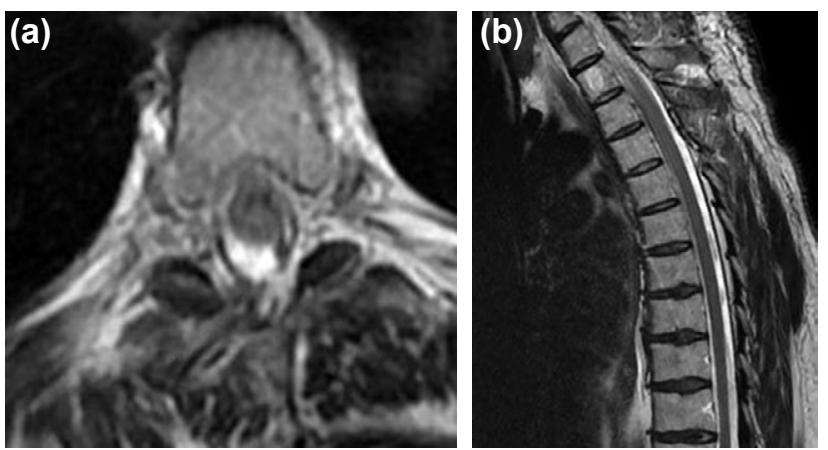

Figure 3. (a, b) Postoperative axial and sagittal MRI images. massage due to long-lasting and occasionally seen low back pain. Half an hour after the back walking massage, she experienced severe back pain and numbness and weakness in her legs.

Laboratory analyses, including platelet count, bleeding time (60-240 seconds), clotting time (300-900 seconds), were within normal limits. Imaging studies (CT and MRI) revealed a lesion in the posterior epidural space consistent with acute hemorrhage at the levels of Th3 and Th4 vertebrae (Fig. 2a-c). At the $12^{\text {th }}$ hour, decompressive hemilaminectomy was performed to Th3-Th4 levels and the hematoma was evacuated. Control MRI was performed within 24 hours postoperatively (Fig. 3a, b). Passive exercises were started on the postoperative second day, and she was referred to the physical therapy program in the second week. In the sixth postoperative month, her leg strength was complete on the left side and 3/5 on the right side, and she was mobilized with support.

\section{DISCUSSION}

$\mathrm{SEH}$ is a rare disease occurring due to bleeding in the epidural region, divided into two main groups, spontaneous and traumatic based on its etiopathogenesis. ${ }^{[1]}$ SHE was first defined by Jackson ${ }^{[5]}$ in 1869 with the autopsy of a young woman who died due to respiratory distress, following a regular loss of strength in the arms and legs. While the pathogenesis of the hematoma has not been fully understood, the majority of the authors believe that the internal posterior epidural venous plexus is the anatomic structure responsible for the hematoma. ${ }^{[6]}$ Causes which rapidly increase the intra-abdominal and thoracic pressure, such as pregnancy, coughing, sneezing, vomiting and urinating, may cause venous epidural plexus lesion. ${ }^{[7]}$ We should note that $40-60 \%$ of the phenomenon is idiopathic-spontaneous; the use of anticoagulant and antiagregant medication is the most frequent underlying causes. ${ }^{[4]}$ Furthermore, SEH development has been reported in cases that cause a tendency to genetic and metabolic coagulopathy, such as vascular malformations, spinal puncture, and use of drugs. ${ }^{[3]}$ Traumatic SEH is frequently observed in adults and males ( $\geq 40$ years old) and cervical (mostly C6 segment) and upper t-spine. It is mostly related to high-energy traumas and vertebral fractures, and $\mathrm{SEH}$ is more likely in patients with rheumatic diseases. ${ }^{[7,8]}$ Some theories have been asserted about the cause of epidural venous hematoma; the main theory is that bone fragment broken in traumatic phenomena directly tears and stretches the epidural veins and cause hemorrhage around the spinal cord..$^{[3,5]}$ However, in high-energy traumatic spinal injuries, no epidural hemorrhage is observed and unlike the assumptions, there is a minor trauma in the majority of the SEH cases. ${ }^{[3]}$ When it comes to minor trauma, it may arise from significant dynamic stress, such as stretching exercises, injuries during physical activities, sports, daily routine activities and chiropractic spinal manipulation therapy. ${ }^{[3,9,10]}$ Even though there are rare phenomena reported with the spinal manipulation therapies, there are not any SEH 
phenomena in the literature related to back walking massage which is an ancient Eastern massage method. Back walking massage is a massage technique that has a historical value in especially Eastern and Far Eastern societies due to nonspecific back pains (Fig. I). The loss of strength and sensation half an hour later than the massage, the lack of damage in bone and ligamentous structures in radiological examinations make us think that damage and hemorrhage has occurred in posterior epidural venous plexus with a minor trauma that arises from back walking massage.

The gold standard technique in diagnostics is MRI; however, it is determinative of the treatment in case of emergency in CT. Hemorrhage in CT is considered as a hyperdense epidural mass. Advantages of CT are that it is easily accessible, cheap, suitable for claustrophobic patients and can be used in patients with a metallic implant. In several cases, surgery with $C T$ can be sufficient to accelerate the treatment. When it comes to MRI, it clearly shows the hematoma pressing on the epidural, vulnerability rate of the cord, lateralization of the hematoma. It is characteristic of SEH that the fusiformlooking lesion in the epidural interval gives a mosaic pattern in irregular intensity depending on methemoglobin degradation. ${ }^{[1]}$

The appearance of clinical findings and the factors determining the severity of the symptom is the amount of hemorrhage, its localization and cord compression time. Because spinal cord is under mechanic pressure, this causes deterioration of microcirculation, central necrosis, edema in axone and myelin sheath and finally causing neurodeficits. ${ }^{[2]}$ Increasing duration of pressure on the spinal cord causes disseminated tissue injury, increase in severity and permanence of deficit. ${ }^{[2]}$ Therefore, surgery is recommended as soon as possible. Early treatment of cord compression can decrease mechanic, histologic and biochemical injuries. Thus, time passing between the surgical intervention with the appearance of symptoms is one of the most important factors. ${ }^{[13]}$ Another important factor that is definitive in the postoperative neurological final condition is a pre-operative neurological examination of the patient. ${ }^{[12,13]}$ The worse is the condition during motor and sensation examination before surgery less is the expectation for post-operative amelioration. Our patient has been on surgery after about 12 hours due to delay that arises from transfer from the epicenter. When the patient came, she was paraplegic and anesthetic. Postoperative, the patient was only able to be mobilized with support in the sixth month. In patients who have no deficit and only pain, spontaneous hematoma resorption and amelioration have been reported with analgesic treatment and rest. However, SEH cases appear with frequently progressive neurological deficits. ${ }^{[10,11]}$ In this case, along with decompression, a hematoma is required to be excreted with urgent surgical intervention. Reaching out to the hemorrhage with total or partial laminectomy decompression can be applied in the cord. ${ }^{[13]}$ Decompression level is determined based on the amount of hemorrhage; however, there is instability risk in long-term levels of laminectomies. Total laminectomy is applied to the areas where hemorrhage is most intense, and hemilaminectomy can be performed in other sections. ${ }^{[13,14]}$

As a result, SEH should be kept in mind in patients with acute symptoms of increased spinal cord pressure. In cases when an MRI may delay the treatment, CT can provide sufficient findings in most of the cases. Even minor trauma may cause $\mathrm{SEH}$. The most determinative characteristic of our case is that a traditional massage method may cause SEH with paraplegia. The literature review has not shown any similar case.

Informed Consent: Written informed consent was obtained from the patient for the publication of the case report and the accompanying images.

Peer-review: Internally peer-reviewed.

Authorship Contributions: Concept: A.Ö., S.D.; Design: A.Ö., E.A.; Supervision: S.D., M.Y.; Materials: A.Ö., O.K.; Data: A.Ö., E.A.; Analysis: A.Ö., E.A.; Literature search: M.Y., O.K.; Writing: E.A.; Critical revision: E.A., A.Ö., O.K.

Conflict of Interest: None declared.

Financial Disclosure: The authors declared that this study has received no financial support.

\section{REFERENCES}

1. Mukerji N, Todd N. Spinal epidural haematoma; factors influencing outcome. Br J Neurosurg 2013;27:712-7. [CrossRef]

2. Caron T, Bransford R, Nguyen Q, Agel J, Chapman J, Bellabarba C. Spine fractures in patients with ankylosing spinal disorders. Spine (Phila $\mathrm{Pa}$ 1976) 2010;35:E458-64. [CrossRef]

3. Domenicucci M, Mancarella C, Santoro G, Dugoni DE, Ramieri A, Arezzo MF, et al. Spinal epidural hematomas: personal experience and literature review of more than 1000 cases. J Neurosurg Spine 2017;27:198-208. [CrossRef]

4. Lidder S, Lang KJ, Masterson S, Blagg S. Acute spinal epidural haematoma causing cord compression after chiropractic neck manipulation: an under-recognised serious hazard?. J R Army Med Corps 2010;156:255-7. [CrossRef]

5. Jackson R. Case of spinal apoplexy. Lancet 1869;2:5-6. [CrossRef]

6. Groen RJ. Non-operative treatment of spontaneous spinal epidural hematomas: a review of the literature and a comparison with operative cases. Acta Neurochir (Wien) 2004;146:103-10. [CrossRef]

7. Hsieh CT, Chiang YH, Tang CT, Sun JM, Ju DT. Delayed traumatic thoracic spinal epidural hematoma: a case report and literature review. Am J Emerg Med 2007;25:69-71. [CrossRef]

8. Anipindi S, Ibrahim N. Epidural Haematoma Causing Paraplegia in a Patient with Ankylosing Spondylitis: A Case Report. Anesth Pain Med 2017;7:e43873. [CrossRef]

9. Lee TH, Chen CF, Lee TC, Lee HL, Lu CH. Acute thoracic epidural hematoma following spinal manipulative therapy: case report and review of the literature. Clin Neurol Neurosurg 2011;113:575-7. [CrossRef]

10. Binnert D, Thierry A, Michiels R, Soichot P, Perrin M. Presentation of a new case of spontaneous spinal extradural hematoma observed during labor. [Article in French] J Med Lyon 1971;52:1307-9.

11. Braun P, Kazmi K, Nogués-Meléndez P, Mas-Estellés F, Aparici-Robles F. MRI findings in spinal subdural and epidural hematomas. Eur J Radiol 2007;64:119-25. [CrossRef] 
12. Akgün B, Sürme MB, Öztürk S, Erol FS. Spontan Spinal Epidural Hematomlar: 12 Olgunun Değerlendirilmesi. FÜ Sağ Bil Tip Derg 2016;30:107-11.

13. Bakker NA, Veeger NJ, Vergeer RA, Groen RJ. Prognosis after spinal cord and cauda compression in spontaneous spinal epidural hematomas.
Neurology 2015;84:1894-903. [CrossRef]

14. Ryu JI, Han MH, Kim JM, Kim CH, Cheong JH. Cervical Epidural Hematoma That Induced Sudden Paraparesis After Cervical Spine Massage: Case Report and Literature Review. World Neurosurg 2018;112:21720. [CrossRef]

\section{OLGU SUNUMU - ÖZET}

\section{Akut spinal epidural hematom: Olgu sunumu ve literatürün gözden geçirilmesi Dr. Ezgi Akar, ${ }^{1}$ Dr. Ahmet Öğrenci, ${ }^{2}$ Dr. Orkun Koban, ${ }^{2}$ Dr. Mesut Yılmaz, ${ }^{3}$ Dr. Sedat Dalbayrak ${ }^{2}$}

${ }^{1}$ Haydarpaşa Numune Eğitim ve Araştırma Hastanesi, Beyin ve Sinir Cerrahisi Kliniği, İstanbul ${ }^{2}$ Okan Üniversitesi Tıp Fakültesi, Beyin ve Sinir Cerrahisi Anabilim Dalı, İstanbul ${ }^{3}$ Nörospinal Akademi, Beyin ve Sinir Cerrahisi Kliniği, İstanbul

Spinal epidural hematom (SEH) omurilik basısı ve nörolojik defisit gelişiminin nadir fakat önemli bir sebebidir. Etyoloji genellikle bilinmez ve acil cerrahi müdahele gerektirir. Bu çalışmada amacımız, nadir bir olgu sunumu ile travmatik SEH'nin klinik önemi, tedavi stratejileri ve tedavi sonrası son durumlarını gözden geçirmektir. Olgumuz 42 yaşında kadın hasta olup, sırt ağrısı, bacaklarda his ve kuvvet kaybı ile başvurdu. Hastanın herhangi bir hastalığı yoktu ve antikoagülan ilaç kullanımıyordu. Hasta, ara sıra olan sırt ağrısından dolayı geleneksel sırt masajı yaptırdıktan yarım saat sonra bacaklarında uyuşma ve kuvvet kaybı ile başvurdu. Hasta kliniğimizde görüldüğünde paraplejik ve T4 altında anestezik idi. Torakal bilgisayarlı tomografi (BT) ve manyetik rezonans görüntülerde (MRG) T3-T4 seviyelerinde posteriyor epidural akut hemoraji izlendi. On ikinci saatte, acil dekompresif hemilaminektomi işlemi yapılarak hematom boşaltıldı. Ameliyat sonrası 24. saatte hastada semptomatik iyileşme görüldü ve altıncı ayda hasta destekle mobilize oluyordu. SEH, ani başlayan sırt ağrısı ve ekstremite güçsüzlüğü olan olgularda akla gelmesi gereken nadir bir durumdur. Tanıda altın standart inceleme MRG olmakla beraber, cerrahi müdahaleyi geciktirmemek için BT çoğu zaman yeterli olabilmektedir. Tanısı koyulan ve nörolojik defisiti olan olgularda acil cerrahi dekompresyon (laminektomi/hemilaminektomi) yapılmalıdır.

Anahtar sözcükler: Dekompresif cerrahi; hemilaminektomi; manyetik rezonans görüntüleme; spinal epidural hematom.

Ulus Travma Acil Cerrahi Derg 2020;26(4):628-631 doi: 10.14744/tites.2019.60956 